\title{
On the Relationship between Adolescents' Dependence on Mobile Phones and their Career Identity
}

\author{
Mihee Han
}

\begin{abstract}
This study intends to identify the relationship between Korean adolescents' dependence on mobile phones and their career identity. The research subjects for this study consisted of a group of 2,091 high school seniors, the 6th year survey of then-7th graders as of 2010 in Korean Children \& Youth Panel Survey. These students are from all over Korea. A set of analysis methods were used to analyze the relationship between the two factors: descriptive statistics, frequency analysis, correlation analysis and regression analysis. It was found from analyzing the collected data that there existed a negative correlation between adolescents' dependence on using mobile phones and their career identity and that the former had a significant effect on the latter. Thus, it might be concluded that students with a higher dependence on mobile phones have a lower degree of career identity. Excessive emphasis on admission to colleges might cause lack of education of career identity.
\end{abstract}

Keywords : adolescents, dependence on mobile phones, career identity, correlation, education.

\section{INTRODUCTION}

It might be true that every adolescent in Korea now possesses a smartphone. It would be hard to image to live without smartphones in this society, whether young or old. The trend can't simply be characterized as the phrase 'the rapidly growing popularity of smartphones'. Simply put, a mobile phone has.

The young generation is often called 'digital native', which perhaps means that a young individual gets literally everything done with a mobile phone and a bunch of applications. An adolescent not only search for information and use information with mobile phones, but also he or she expresses himself or herself with mobile phones. Such a trait can distinguish this young generation from older generations, and it may follow that adolescents should be educated and encouraged to use mobile phones in a desirable way for healthy purposes[1].

Many researches have reported in the literature that adolescents' excessive and undesirable use of cellular phones might bring about negative or sometimes serious problems. Being able to do everything with a smartphone, lose their control ability, which has become a new social problem[2].

Behind the scene of their increasing dependence on mobile phones seems to be the agreement of society that each student should make every effort to get better score in order to get admitted to better colleges. Extremely intensive competition

Revised Manuscript Received on July 22, 2019.

Mihee Han*, Deft of General Education, Namseoul University, Cheonansi, S. Korea. diaplus@nsu.ac.kr in education and heavy emphasis on better scores and grades can lead young students to appeal to and depend more on the use of mobile phones. Lack of cultural environments to produce comfortable psychological state and absence of helpers and mentors around them would let them make friends with mobile phones.

\section{THEORETICAL BACKGROUND}

\section{A. Understanding Dependence on Mobile Phones}

With rapid expansion of the ubiquitous networks, the influence of mobile phones on adolescents' values and behavior has enormously increased. A mobile phone is not an electronic appliance used in a particular circumstance any more. It is now used anytime anywhere in every aspect of daily life of everybody, young or old. In particular, for adolescents, it is a crucial and essential method of making and maintaining relationship with friends and their peer group.

Their use of smartphones is very likely to increase and, as a consequence, a growing concern on the negative sides of smartphone use has recently attracted much attention from society. However, a positive side of the same issue would be that mobile phones can be very helpfully used for adolescents' academic use and some aspects of daily lives including getting connected with and having communication with parents and friends[4].

In fact, to many young students, communication with friends topped the list of purposes for using mobile phones and keen interest in peer relationship would often lead to greater dependence on mobile phones[5]. Likewise, for many adolescents, a mobile phone is used as a space to establish emotional ties with peers, avoid getting alienated from friends and maintaining relationship. Thus, if used properly, a mobile phone may provide a channel for positive relationship, but excessive dependence on mobile phones may also prevent young students from establishing a variety of relationship with peers, which could be the source of alienation. Furthermore, it was reported that adolescents' free use of mobile phones can have a negative effect on their adjustment to school life [6].

It might be safely assumed that excessive dependence on mobile phones can cause psychological problems, which can't be ignored. Mobile services include a variety of activities and contents, as shown below in the table 1. College students, thus, are apt to depend a great deal on mobile devices[7].

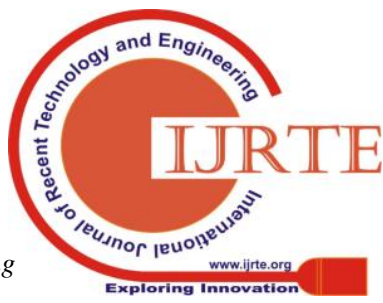


Table - I: trends for mobile service

\begin{tabular}{|c|c|}
\hline Segment & Trend \\
\hline voice calls & addition of multilateral communication \\
\hline video calls & diversity of display styles \\
\hline \multirow{7}{*}{ call options } & customized management service \\
\hline & selective use of phone numbers \\
\hline & selective reception of contents \\
\hline & diversity and simplification of dialing \\
\hline & living information via voice \\
\hline & selective prohibition of outgoing calls \\
\hline & protection of privacy \\
\hline \multirow{4}{*}{ phone directory } & diversity of search conditions \\
\hline & automatic/manual input \\
\hline & management of groups and speed dialing \\
\hline & Transcendence of location \\
\hline Text messages & $\begin{array}{l}\text { multimedia messages } \\
\text { Real time messages \& multimedia } \\
\text { communication }\end{array}$ \\
\hline chatting & $\begin{array}{l}\text { Real time messages \& multimedia } \\
\text { communication }\end{array}$ \\
\hline $\begin{array}{l}\text { multimedia } \\
\text { message }\end{array}$ & $\begin{array}{l}\text { diversity of multimedia messages \& } \\
\text { communication styles }\end{array}$ \\
\hline location info & mobile navigation services \\
\hline Web mails & enhanced mobile services with web \\
\hline $\begin{array}{l}\text { service } \\
\text { messages }\end{array}$ & $\begin{array}{ll}\text { business services } & \text { beyond } \\
\text { input-orientation } & \end{array}$ \\
\hline message content & diversity in message decoration \\
\hline $\begin{array}{l}\text { spam } \\
\text { management }\end{array}$ & $\begin{array}{l}\text { management of increasing spam } \\
\text { messages }\end{array}$ \\
\hline file storage & $\begin{array}{l}\text { outgoing files via mobile diversity \& } \\
\text { fragmentation of options }\end{array}$ \\
\hline System Lock & \multirow{4}{*}{$\begin{array}{l}\text { fragmentation diversity and } \\
\text { fragmentation of security functions for } \\
\text { systems due to increasing and } \\
\text { diversified online services }\end{array}$} \\
\hline Password & \\
\hline System initialize & \\
\hline System Setting & \\
\hline $\begin{array}{l}\text { networking } \\
\text { widget }\end{array}$ & $\begin{array}{l}\text { networking between a set of mobile } \\
\text { services }\end{array}$ \\
\hline $\begin{array}{l}\text { non networking } \\
\text { widget }\end{array}$ & $\begin{array}{l}\text { management of personal schedules \& } \\
\text { job assistance }\end{array}$ \\
\hline movie & Increasing video contents and UCC \\
\hline music & music accessible anytime anywhere \\
\hline TV & DMB accessible anytime anywhere \\
\hline Game & diversified game types \\
\hline Web browsing & web browsing \\
\hline navigation & $\begin{array}{l}\text { GPS-based services useful in emergency } \\
\text { situations }\end{array}$ \\
\hline shopping & $\begin{array}{l}\text { tansition from web to mobile increasing } \\
\text { mobile banking }\end{array}$ \\
\hline information & $\begin{array}{lll}\text { information } & \text { accessible } & \text { anytime } \\
\text { anywhere } & & \end{array}$ \\
\hline security & diversification of security-realted service \\
\hline health & contents in place of health trainers \\
\hline study & $\begin{array}{l}\text { study contents accesible anytime } \\
\text { anywhere incrase in users' movement } \\
\text { and changing life styles }\end{array}$ \\
\hline decoration & service for individualization need \\
\hline
\end{tabular}

\section{B. Understanding career identity of adolescents}

Career identity refers to an individual' perception of his or her characteristics and competencies and of acceptable career roles to realize the self. Thus, a career identity is closely related with one's accurate understanding of oneself and confidence in one's abilities by which one can make suitable decisions when facing vagueness or ambiguity [8]. Holland (1985) defines career identity as the formation of stable image of one's career goal, interests, and competencies[9]. Such a formed image can, then, act as the basis of linking oneself to the work-related world by understanding the world of a chosen profession and establishing effective career plans. It is natural that anxiety over career is closely related with career identity[10].

Formation of a career identity should start, first of all, with better understanding of the self. With that understanding, one can, then, make a decision on the career paths by considering a variety of factors including his or her interests and abilities.

In particular, a 12th grader, who is about to choose a major field at college, should base his decision on his or her career identity[11].

As a consequence, education of career identity and career search should be expanded in order to help secondary school students make right decisions on their academic majors, which would be closely related with their career paths.

\section{MEASUREMENT SCALES}

\section{A. Measurement scales Independence on mobile Phones}

The scale examining adolescents' dependence on mobile phones consisted of a total of 7 items. used in the 7 th year survey of Korean Child \& Youth Panel Survey(KCYPS), the longitudinal study lasting for 7 years for the same group of subjects. Each item was measured on a 4 point Likert scale: 1 point for strongly disagree, 2 for disagree, 3 for agree, and 4 for strongly agree. Thus, a higher score would mean a higher level of one's dependence on mobile phones. The Cronbach's a was obtained at .710. The content of the items can be found below in Table 2 Analysis, Comparative Investigation, Investigation.

Table- II: Items for dependence on mobile phones

\begin{tabular}{|l|l|}
\hline Item & content \\
\hline 1 & $\begin{array}{l}\text { I spend more and more time in using mobile } \\
\text { phones. }\end{array}$ \\
\hline 2 & $\begin{array}{l}\text { I feel uneasy without having a smartphone with } \\
\text { me. }\end{array}$ \\
\hline 3 & $\begin{array}{l}\text { I feel uneasy if i don't get any calls or messages } \\
\text { from others for a while. }\end{array}$ \\
\hline 4 & $\begin{array}{l}\text { I am unaware of the passage of time, doing this } \\
\text { and that with a mobile phone. }\end{array}$ \\
\hline 5 & $\begin{array}{l}\text { I feel bored without a mobile phone, when I am } \\
\text { alone by myself. }\end{array}$ \\
\hline 6 & I feel isolated without a mobile phone. \\
\hline 7 & $\begin{array}{l}\text { It would be very inconvenient to live without a } \\
\text { smartphone }\end{array}$ \\
\hline
\end{tabular}

Table 2 shows that the measurement items for dependence on mobile phones are expressive of addiction to mobile phones. We can easily picture an image of an adolescent holding a mobile phone anytime anywhere. 


\section{B. Career identity}

It consisted of a total of 8 measurement items. Each item was measured on a 4 point Likert scale. A higher score would mean a higher level of sense of career identity. The Cronbach's a was obtained at .88. The content of the items can be found below in Table 3

Table- III: Items for career identity

\begin{tabular}{|l|l|}
\hline Item & Content \\
\hline 1 & $\begin{array}{l}\text { I have a specific profession I would really like } \\
\text { to work in. }\end{array}$ \\
\hline 2 & $\begin{array}{l}\text { I would not follow parents' advice for me to } \\
\text { choose the major field I don't want. }\end{array}$ \\
\hline 3 & $\begin{array}{l}\text { I have basically made up my mind for the } \\
\text { overall picture of my life. }\end{array}$ \\
\hline 4 & $\begin{array}{l}\text { I have a specific field in my mind for my } \\
\text { major at college }\end{array}$ \\
\hline 5 & I have to decide on my profession on my own. \\
\hline 6 & $\begin{array}{l}\text { I want a particular occupation for an obvious } \\
\text { reason. }\end{array}$ \\
\hline 7 & $\begin{array}{l}\text { I have known since childhood what } \\
\text { profession I would like to work in. }\end{array}$ \\
\hline 8 & $\begin{array}{l}\text { I can talk to others with confidence about my } \\
\text { future plan. }\end{array}$ \\
\hline
\end{tabular}

As shown in Table 3, this scale for career identity contains the questions asking whether one has a clear image of the world of profession and, thus, can express his or her opinion of career plan with confidence. In other words, one's formation career identity in oneself refers to the process of searching for the self, searching for information on a profession and making decisions on a career path he or she would like to pursue.

\section{Analysis Method}

A series of analytical methods were employed to address the issue under discussion for the current research descriptive statistics, correlation analysis, multi-regression analysis.

\section{RESEARCH RESULTS}

\section{A. Descriptive statistics}

The means and standard deviation(SD) of adolescents' dependence on mobile phones and their career identity are illustrated below in Table 4 .

Table- IV: Mean and standard deviation

\begin{tabular}{|l|c|c|c|c|}
\hline \multicolumn{1}{|c|}{ Factors } & minimum & maximum & Mean & $\begin{array}{c}\text { Standard } \\
\text { Deviation }\end{array}$ \\
\hline $\begin{array}{l}\text { dependence } \\
\text { on mobile } \\
\text { phones }\end{array}$ & 1.00 & 4.00 & 2.6851 & .63971 \\
\hline $\begin{array}{l}\text { career } \\
\text { identity }\end{array}$ & 1.00 & 4.00 & 1.9822 & .58947 \\
\hline
\end{tabular}

Table 4 shows that the mean and standard deviation of the research subjects' dependence on mobile phones were obtained at 2.6851 and .63971 , respectively. Those for their career identity, in turn, were 1.9822 and .58947 , respectively.

\section{B. Correlation analysis}

Correlation between adolescents' dependence on mobile phones and their career identity

For the purpose of examining the issue under discussion, a correlation analysis of the two factors was performed and the result of the analysis can be found below in Table 5

Table- V : Correlation between adolescents' dependence on mobile phones and their career identity

\begin{tabular}{|l|c|c|}
\hline \multicolumn{1}{|c|}{ Factors } & {$[1]$} & {$[2]$} \\
\hline dependence on mobile phones [1] & 1 & \\
\hline career identity [2] & $106^{* *}$ & 1 \\
\hline
\end{tabular}

Table 5 shows that there existed a significant negative correlation between adolescents' dependence on mobile phones and their career identity.

Correlation between adolescents' dependence on mobile phones and subfactors of their career identity

A correlation analysis of adolescents' dependence on mobile phones and subfactors of their career identity was conducted, whose results can be summarized as in Table 6.

Table- VI: correlation between adolescents' dependence on mobile phones and subfactors of their career identity

\begin{tabular}{|c|c|c|c|c|c|c|c|c|c|c|c|c|c|c|c|}
\hline & \multicolumn{7}{|c|}{ subfactors of dependence on mobile phones } & \multicolumn{8}{|c|}{ subfactors of career identity } \\
\hline & {$[1]$} & [2] & [3] & {$[4]$} & [5] & [6] & [7] & {$[8]$} & [9] & {$[10]$} & {$[11]$} & {$[12]$} & [13] & {$[14]$} & [15] \\
\hline [1] & 1 & & & & & & & & & & & & & & \\
\hline [2] & $.418^{* *}$ & 1 & & & & & & & & & & & & & \\
\hline [3] & $.302 * *$ & $.509 * *$ & 1 & & & & & & & & & & & & \\
\hline [4] & $.534 * *$ & $.374 * *$ & $.316^{* *}$ & 1 & & & & & & & & & & & \\
\hline [5] & $.492 * *$ & $.549 * *$ & $.465 * *$ & $.492 * *$ & 1 & & & & & & & & & & \\
\hline [6] & $.361^{* *}$ & $.551 * *$ & $.602 * *$ & $.358 * *$ & $.598 * *$ & 1 & & & & & & & & & \\
\hline [7] & $.389^{* * *}$ & $.607 * *$ & $.441 * *$ & $.380 * *$ & $.622 * *$ & $.647 * *$ & 1 & & & & & & & & \\
\hline [9] & $-.052^{*}$ & -.031 & $-.076^{* *}$ & -.034 & $.083^{* *}$ & $-.045^{*}$ & $-.049 *$ & $.331 * *$ & 1 & & & & & & \\
\hline [10] & $-.053^{*}$ & -.043 & $-.057^{*}$ & -.037 & $-.078^{* *}$ & -.036 & $-.055^{*}$ & $.656^{* * *}$ & $.348 * *$ & 1 & & & & & \\
\hline [11] & $-.062^{* *}$ & $-.054 *$ & $-.086^{* * *}$ & -.041 & $-.083^{* *}$ & -.066 *** & $-.098 * *$ & $.638 * *$ & $.281 * *$ & $.609 * *$ & 1 & & & & \\
\hline [12] & -.042 & $-.057 *$ & $-.100 * *$ & -.031 & $-.087 * *$ & $-.087 * *$ & $-.079 * *$ & $.474 * *$ & $.390 * *$ & $.479 * *$ & $.513 * *$ & 1 & & & \\
\hline [13] & $-.102^{* * *}$ & $-.067 * *$ & $-.056^{*}$ & $-.055^{*}$ & $-.101 * *$ & -.070 *** & $-.113 * *$ & $.672 * *$ & $.314 * *$ & $.617 * *$ & $.621 * *$ & $.510^{* * *}$ & 1 & & \\
\hline [14] & $-.079 * *$ & -.032 & .000 & $-.063 * *$ & $-.048^{*}$ & -.006 & $-.056^{*}$ & $.502 * *$ & $.236 * *$ & $.478 * *$ & $.432 * *$ & $.326^{* *}$ & $.569 * *$ & 1 & \\
\hline [15] & $-.074 * *$ & $-.055^{*}$ & -.035 & $-.052 *$ & $-.073^{* *}$ & -.024 & $-.060 * *$ & $.646 * *$ & $.307 * *$ & $.702 * *$ & $.597 * *$ & $.458^{* * *}$ & $.672 * *$ & $.592 * *$ & 1 \\
\hline
\end{tabular}

$* \mathrm{p}<.05, * * \mathrm{p}<.01$

Table 6 shows that a significant negative correlation was found between adolescents' dependence on mobile phones and subfactors of their career identity. (1; I spend more and more time in using mobile phones . 2; I feel uneasy without having a smartphone with me. 3 ; I feel uneasy if i don't get any calls or messages from others for a while. 4; I am unaware of 
the passage of time, doing this and that with a mobile phone. 5 ; I feel bored without a mobile phone, when I am alone by myself. 6; I feel isolated without a mobile phone. 7; It would be very inconvenient to live without a smartphone. 8 ; I have a specific profession I would really like to work in. 9; I would not follow parents' advice for me to choose the major field I don't want reason. 14; I have known since childhood what profession I would like to work in. 15; I can talk to others with confidence about my future plan)

\section{Descriptive statistics}

- Variance analysis

The ANOVA analysis of adolescents' dependence

The ANOVA analysis of adolescents' dependence on mobile phones and their career identity found the following results as in Table 7 .

Table -VII: variance analysis of adolescents' dependence on mobile phones and their career identity

\begin{tabular}{|l|l|l|l|l|l|}
\hline Model & $\begin{array}{l}\text { sum of } \\
\text { squares }\end{array}$ & $\begin{array}{l}\text { degree of } \\
\text { freedom }\end{array}$ & $\begin{array}{l}\text { mean } \\
\text { square }\end{array}$ & F & $\begin{array}{l}\text { significance } \\
\text { probability }\end{array}$ \\
\hline Regression & 7.867 & 1 & 7.867 & 22.910 & $.000 * * *$ \\
\hline Residual & 691.255 & 2013 & .343 & & \\
\hline Total & 699.122 & 2014 & & & \\
\hline
\end{tabular}

$* \mathrm{p}<.05, * * \mathrm{p}<.01, * * * \mathrm{p}<.001$

Table 7 shows that the $\mathrm{F}$ value was 22.910 , which means that the regression model is significant at the significance level of $\mathrm{p}<.001$.

Regression analysis of adolescents' Regression analysis of adolescents' dependence on Mobile phones and their career identity

The regression analysis of adolescents' dependence on mobile phones and their career identity found the following results in Table 8.

Table- VIII : Coefficient between dependence on mobile phones and career identity

\begin{tabular}{|l|l|l|l|l|l|}
\hline Model & \multicolumn{2}{|l|}{$\begin{array}{l}\text { nonstandardized } \\
\text { coefficient }\end{array}$} & $\begin{array}{l}\text { standardized } \\
\text { coefficient }\end{array}$ & $\mathrm{t}$ & $\begin{array}{l}\text { significance } \\
\text { probability }\end{array}$ \\
\hline & $\mathrm{B}$ & $\begin{array}{l}\text { standard } \\
\text { error }\end{array}$ & Beta & & \\
\hline (constant) & 2.245 & .056 & & 39.844 & \\
\hline $\begin{array}{l}\text { dependence } \\
\text { on mobile } \\
\text { phones }\end{array}$ & -.098 & .020 & -.106 & - & $.000 * * *$ \\
\hline
\end{tabular}

As exhibited in Table 8 , the regression analysis of adolescents' dependence on mobile phones and their career identity found that the significance probability was less than $\mathrm{p}<.05$, which signifies that their dependence on mobile phones had a significant effect on their career identity

\section{CONCLUDING REMARKS}

Adolescents' excessive dependence on mobile phones might cause serious problems in many aspects including psychological and social perspectives. It might often lead to a young student give up his or her academic life and drop out of school. More common forms of side effects might include depression, loss of control or lack of concentration. The period of adolescence is a crucial time for any young student and one of the most important tasks for this period would be try to look into oneself and form a career identity for the future. Such an important but difficult task can be a very challenging one for young students, thus, it would require systematic and interesting programs to help enhance their self-esteem and seek a desirable career identity.

\section{ACKNOWLEDGMENT}

Funding for this paper was provided by Namseoul University.

\section{REFERENCES}

1. P. H. Jung, C. R. Nho, K. S. Lee, H. S. Min, J.D.Song, "Mediating Effects of Depression and Aggression on the Association between Child Abuse and Neglect and Cell Phone Addiction -Gender Comparison" Journal of the Korean society of child welfare., Sep; 47, 93-123, 2014

2. H.L Yang, Y.J Yoon, B.Y Jung, Emery Clifton R, "The Effects of Parental Abuse and Aggression on Mobile Phone Dependency - Focused on the Moderated Mediation Effect of Youth Activity" Journal of the Korea Institute of Youth Facility and Environment., Jul; 14(2), 5-15. 2016.

3. Y.A Kim, "The influence of experience activity of youth on career identity" Studies on Korean Youth Activity., Jul, 4(1), 21-41. 2018.

4. Y.S. Sung, "Mobile Phone Dependency and Social Delinquency among Korean Adolescents" Studies on Korean Youth., Dec; 17(2): 291-321, 2006.

5. D.H. Kim , H.C. Yang, "The effects of ecological factors on the trajectory of cellular phone dependency during the middle school years" Studies on Korean Youth., Aug; 25(3), 169-197, 2014.

6. J.Y. Lee, I.J. Chung, Y.D. Jang, Y.H. Ju , "The Effect of Mobile-phone Dependency on School Adjustment: Focusing on the Moderating Effect of Self-Esteem and Gender Difference" Journal of Youth Welfare., Sep; 17(3), 1-15, 2015

7. K.M. Kim, H.J. Lee, "Analysis of current Mobile Service Application and Mobile Service Design Strategies in Ubiquitous smart space" Journal of Digital Design., Jan; 9(1), 413-422, 2009.

8. Tiedeman, D. V. \& O'Hara, R. P, Career development: choice and adjustment., NY: College Entrance Examination Board, 1963.

9. Holland, J. L. Making Vocational Choices: A Theory of Vocational Personalities and Work Environments. Englewood Cliffs, NJ : Prentice-Hall, 1985.

10. I.S. Shin, Y.O. Jang, "The effects of career exploration programs using career portfolio and teacher-directed on the career maturity and career identity in middle school students" Korean Home Economics Education Association., Mar; 24(1), 85-104, 2012.

11. E.J. Park, Y.R. Lee, S.H. Lee, "The Effects of Adolescents" Social Capital on Their Career Identification by Parents Income Strata : Focusing. Korean Journal of Youth Studies., May; 3(5), 237-263, 2016.

\section{AUTHORS PROFILE}

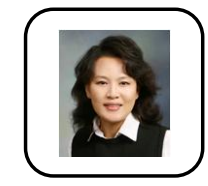

Mihee Han Namseoul University, Dept of General Education, 91 Daehakro Seonghwaneup Sebukgu Cheonansi Chungcheongnamdo, S. Korea Education Contents: Multimedia learning, Measurements and Evaluations, Counseling Psychology. 